DOI : https://doi.org/10.24123/jbt.v5i1.4062

\title{
PENGARUH ETIKA KEPEMIMPINAN, FUNGSI BADAN PENGAWAS, TINGKAT PEMAHAMAN AKUNTANSI TERHADAP KUALITAS PELAPORAN KEUANGAN LPD DI KOTA DENPASAR
}

\author{
Desak Ayu Sriary Bhegawati ${ }^{1}$, Ni Nyoman Ari Novarini ${ }^{2}$ \\ ${ }^{1,2}$ Faculty Of Economy and Bussiness, Mahasaraswati Denpasar University \\ Email : desak.bhegawati@gmail.com
}

\begin{abstract}
Village Credit Institutions are microfinance institutions that reflect the existence of a community in society based on the principles of Balinese customary law. There are 4 problems with the hypothesis of this study, namely leadership ethics has a positive effect on the quality of financial reporting, the function of the Supervisory Body has a positive effect on the quality of financial reporting, Work experience has a positive effect on the quality of financial reporting. The level of accounting comprehension has a positive effect on the quality of financial reporting. Sampling of this study used saturated sampling with all 35 LPD units studied in Denpasar City. The analytical tool used in this research was Multiple Linear Regression., the results of the study showed that Leadership Ethics, the function of the supervisory body, and the level of accounting understanding have a positive effect on the quality of financial reports at LPDs in Denpasar City. While work experience has no effect on the quality of financial reports at LPDs in Denpasar City. Improving the performance of LPD managers, especially the chairman, must prioritize leadership ethics. In addition, the function of the supervisory body is always improved and refers to procedures according to the rules for presenting financial statements. Accounting understanding also continues to be improved. Employee training continues to be improved because it provides more work roles for the LPDs so that the performance of the Denpasar City LPD continues to increase.
\end{abstract}

Keyword : Quality of Financial Statements, Leadership Ethics, Supervisory Body Functions, Level of Accounting Understanding

\section{Pendahuluan}

Lembaga Perkreditan Desa yang biasa disebut dengan LPD sebagai salah satu lembaga keuangan mikro yang mencerminkan adanya komunitas pada masyarakat berdasarkan atas prinsip hukum adat di Bali. Lembaga keuangan mikro tersebut memiliki karakter yang sangat khas karena sebagai lembaga komunitas yang tercipta dan didirikan untuk masyarakat yang ada di desa pakraman (Putri et al., 2018).Peranan Lembaga Perkreditan Desa (LPD) sebagai sebagai Badan Usaha Milik Desa yang dikelola desa adat pakraman dengan operasionalnya untuk kegiatan perekonomian di masyarakat 
Pengelolaan yang dilakukan LPD tersebut, membutuhkan seorang pemimpin yang memiliki etika yang baik, agar LPD yang dijalankan dapat terus berkembang (Holt et al., 2018).Pentingnya etika yang dimiliki oleh seorang pemimpin akan berdampak pada efektifnya operasional usaha dan organisasi dapat berjalan dengan seimbang. Nilai tambah dalam mendorong pengembangan diri untuk meningkatkan mental dan spiritual harus dijunjung oleh pemimpin organisasi dalam menjalankan tugas etika kepemimpinannya (Purba dkk., 2020). Oleh karena itu karyawan dalam suatu organisasi memiliki kepercayaan kepada pemimpinnya, khususnya dalam mengelola LPD. Operasional kerja LPD tersebut dalam membuat laporan keuangan akan meningkatkan kualitasnya karena karyawan dapat terlatih dengan kompeten sehingga laporan keuangan yang dihasilkan sesuai dengan norma dan nilai yang bisa diterima oleh masyarakat (Arowoshegbe et al., 2017).

Nilai dan norma moral adalah penentu dari perilaku seseorang dalam menjalankan kehidupannya hal ini berdasarkan cabang ilmu filsafat dikenal dengan etika (Munirah, 2020). Strategi yang dilakukan oleh pemimpin beserta karyawannya berpedoman pada kaidah, nilai, dan norma yang ada di masyarakat sehingga berhubungan dengan etika yang dilakukan pemimpin. Pengawasan secara intern yang penting dilakukan salah satunya dalam proses pengauditan merupakan kerjasama yang dilakukan dalam menumbuhkan kinerja LPD.Oleh karena itu, fungsi badan pengawas adalah berperan mengawasi kebijakan yang dilakukan termasuk operasional kegiatan usaha (Rahayu dkk., 2020).

Karyawan yang memiliki pengalaman dan kemampuan dalam menyelesaikan tugas-tugas yang berkaitan dengan penyusunan laporan keuangan dapat membantu meningkatkan kualitas laporan keuangan. Pengalaman kerja yang dimiliki oleh karyawan LPD tersebut menjadi pendukung kualitas kerja karena masa kerja lebih banyak dan ilmu yang dimiliki mengelola LPD dapat diandalkan (dewi et al., 2019).Penyusunan laporan keuangan yang sangat penting dilakukan adalah pemahaman akuntansi yang dimiliki oleh pengelola LPD tersebut. Pemahaman akuntansi yang dimiliki akan meningkatkan kualitas laporan keuangan karena dibuat dengan kejujuran dan berdasarkan atas peraturan standar akuntansi keuangan sehingga dapat terbebas dari ketimpangan informasi atas pengetahuan akuntansi yang diperoleh (Agung dan Mulyani, 2020).

Kondisi kesehatan keuangan pada suatu perusahaan yaitu LPD dapat dilihat dari laporan keuangan. Laporan keuangan yang disajikan oleh LPD cenderung dipengaruhi oleh unsur internal seperti masyarakat setempat yang memilih Ketua LPD melalui musyawarah tanpa memperhatikan pengalaman yang dimiliki maupun pendidikan dari ketua LPD tersebut.Oleh karena itu, dalam penyusunan laporan keuangan banyak terjadi kendala karena kurangnya pemahaman pengelola LPD termasuk karyawan dalam menata keuangan perusahaan (Permatasari dan Agustina, 2021). Lembaga Perkreditan Desa (LPD) di Kota Denpasar kondisinya terus mengalami pertumbuhan yang cukup pesat, hal tersebut dikarenakan sistem adat yang kuat sehingga membuat LPD menjadi lembaga keuangan yang berpotensi dalam mendukung perekonomian masyarakat.Sistem adat yang kuat yang menjiwai mental, pola, dan sikap dari masyarakat ini memberikan pengaruh yang baik dalam peningkatan kinerja LPD di Kota Denpasar (Sari dan Suindari, 2020). Berdasarkan latar belakang tersebut penelitian ini bertujuan untuk mengetahui pengaruh Etika Kepemimpinan, Fungsi Badan 
Pengawasan, Pengalaman Kerja Dan Tingkat Pemahaman Akuntansi Terhadap Kualitas Pelaporan Keuangan Pada Lembaga Perkreditan Desa (LPD) Di Kota Denpasar.

\section{Landasan Teori}

Teori kelembagaan atau institusional theory adalah teori yang menjelaskan tentang bagaimana suatu perusahaan dapat bertumbuh dan berkelanjutan ketika berada dalam lingkungan yang kompetitif yang penuh dengan para pesaing, dan perusahaan memiliki kemampuan dalam menggandeng stakeholder. Adanya ketidakpuasan dan rasa tidak percaya terhadap teori neoklasik sehingga menimbulkan adanya konsep kelembagaan sebagai bagian dari ilmu ekonomi dengan satu kesatuan ilmu sosial, seperti psikologi, sosiologi, politik, antropologi, sejarah dan hukum. Berdasarkan hal tersebut masuk kedalam inti pokok pokok aliran ekonomi kelembagaan (Petrakis, 2020).

Kepemimpinan etis dapat berarti kemampuan dan kesiapan seseorang dalam memberikan pengaruh dan menuntun seseorang maupun kelompok untuk mencapai tujuan bersama dengan berdasarkan atas nilai-nilai moral. Nilai-nilai moral yang di maksud adalah seperti akhlak, rasa tanggung jawab, menghargai, budi pekerti, disiplin, kerja keras, jujur dan religius (Ellemers, 2017). Pengawasan merupakan strategi yang dilakukan untuk menetapkan kinerja standar pada perencanaan untuk merancang sistem umpan balik informasi, untuk membandingkan kinerja aktual dengan standar yang telah ditentukan, untuk menentukan apakah telah terjadi suatu penyimpangan tersebut, serta untuk mengambil tindakan perbaikan yang diperlukan untuk menjamin bahwa semua sumber daya perusahaan atau pemerintahan telah digunakan seefektif dan seefisien mungkin guna mencapai tujuan perusahaan atau pemerintahan (Alferjany et al., 2018).

Pengalaman kerja merupakan lama kerja pengawas intern pada perusahaan. Semakin lama seorang pengawas intern bekerja pada perusahaan tersebut maka akan dapat meningkatkan dan mengembangkan kemampuannya dalam melakukan tugas audit (Sari dan Susanto, 2018). Pengalaman kerja sangat dibutuhkan dalam setiap pekerjaan. Pengalaman kerja akan memberikan kita petunjuk dan pembelajaran tentang bagaimana cara mengatasi setiap permasalahan yang ada.

Pemahaman merupakan proses, cara, perbuatan memahami dan memahamkan, sehingga orang yang memiliki pemahaman akuntansi adalah orang yang pandai dan mengerti benar tentang akuntansi. Seseorang dikatakan paham terhadap akuntansi berarti mengerti dan pandai bagaimana proses akuntansi itu dilakukan sampai menjadi suatu laporan keuangan dengan berpedoman pada prinsip dan standar penyusunan (Goddard, 2020).

Laporan keuangan adalah catatan informasi suatu entitas pada suatu periode akuntansi yang dapat digunakan untuk menggambarkan kinerja entitas tersebut. Laporan keuangan merupakan laporan yang terstruktur mengenai posisi keuangan dan transaksitransaksi yang dilakukan oleh suatu entitas pelaporan (Lantto, 2020).Tujuan umum laporan keuangan adalah menyajikan informasi mengenai posisi keuangan, realisasi anggaran, arus kas, dan kinerja keuangan suatu entitas pelaporan yang bermanfaat bagi para pengguna dalam membuat dan mengevaluasi keputusan mengenai alokasi sumber daya. Kualitas laporan keuangan merupakan hasil informasi yang berguna bagi pengguna dalam menyediakan informasi sesuai karakteristik kualitatif informasi atau karakteristik 
kualitas informasi keuangan (Agustina dan Setyaningrum, 2020). Untuk memenuhi kualitas informasi akuntansi, maka informasi bisa dimengerti oleh para pengambil keputusan dalam menyusun sebuah laporan keuangan berkualitas, terdapat empat karakteristik kualitatif laporan keuangan yang harus diperhatikan, yaitu dapat dipahami, relevan, andal, dan dapat dibandingkan (Zulkarnain dan Ningrum, 2020). Berdasarkan konsep tersebut adapun hipotesis penelitian dapat disusun sebagai berikut.

\section{Hubungan antara Etika Kepemimpinan dengan Kualitas Pelaporan Keuangan.}

Pemimpin harus menyatukan keterampilan, pengalaman, kepribadian, dan motivasi setiap pemimpin. Berdasarkan pengalaman kerja secara keseluruhan, karyawan menganggap pemimpin sebagai pemimpin yang efektif.Oleh karena itu, menerima instruksi atau persyaratan pemimpin sangat bergantung pada harapan pengikut mereka (Ivancevich, 2001).Semakin baik etika kepemimpinan yang dimiliki oleh seorang ketua maka semakin berkualitas pada pelaporan keuangan.

$\mathrm{H}_{1}$ : Etika Kepemimpinan berpengaruh positif terhadap kualitas pelaporan keuangan.

\section{Hubungan antara Fungsi Badan Pengawas dengan Kualitas Pelaporan Keuangan.}

Peranan badan pengawas internal terletak pada pengawasan efektivitas kebijakan operasi, praktik akuntansi, laporan keuangan, dan pengawasan efektivitas hubungan antara manajer dan auditor eksternal. Ketika mengumpulkan terlalu banyak dana di masyarakat dan bertindak sebagai pengawas dalam menjalankan kredit dan mengelola diversifikasi risiko, kredit tidak hanya terkonsentrasi pada debitur tertentu (Wedayani \& Jati, 2012).Semakin ditingkatkan tugas dari badan pengawas internal, maka akan semakin meningkatkan kualitas pelaporan keuangan.

$\mathrm{H}_{2}$ : Fungsi Badan Pengawas berpengaruh positif terhadap kualitas pelaporan keuangan.

\section{Hubungan antara Pengalaman Kerja dengan Kualitas Pelaporan Keuangan.}

Pengalaman kerja berarti seseorang yang sudah pernah bekerja termasuk lama bekerja sesuai bidang pekerjaan yang digeluti dan memiliki jabatan pekerjaan. Pengalaman pegawai/karyawan tersebut memiliki kemampuan dalam membagikan tugas pokok maupun fungsi serta tanggung jawab berdasarkan struktur organisasi dan standar operasional prosedur yang ada (Charolina dkk., 2013). Semakin tinggi pengalaman bekerja yang dimiliki seseorang maka akan meningkatkan kualitas pelaporan keuangan.

$\mathrm{H}_{3}$ : Pengalaman Kerja berpengaruh positif terhadap kualitas pelaporan keuangan.

\section{Hubungan antara Tingkat Pemahaman Akuntansi dengan Kualitas Pelaporan Keuangan.}

Pemahaman akuntansi merupakan salah satu kunci dalam menawarkan dan digunakan sebagai pemanfaatan laporan keuangan. Pendidikan Akuntansi diajukan dalam mendidik mahasiswa sehingga mempunyai pengetahuan dalam bidang akuntansi. Penyusunan laporan keuangan, akuntan mempunyai pemahaman terhadap isi dalam laporan tersebut, sehingga dapat membuat keputusan untuk dilaksanakan (Nuraini, 2007).Semakin luas memiliki pemahaman akuntansi maka akan dapat meningkatkan kualitas pelaporan keuangan.

$\mathrm{H}_{4}$ : Tingkat Pemahaman Akuntansi berpengaruh positif terhadap kualitas pelaporan keuangan. 


\section{Metode Penelitian}

Penelitian ini dilaksanakan pada LPD yang berada di Kota Denpasar terdapat 35 LPD di 4 Kecamatan yaitu Kecamatan Denpasar Selatan, Kecamatan Denpasar Utara, Denpasar Barat, Denpasar Timur. Objek penelitian ini meliputi etika kepemimpinan, fungsi badan pengawas, pengalaman kerja dan tingkat pemahaman akuntansi terhadap kualitas pelaporan keuangan pada Lembaga Perkreditan Desa. Metode yang digunakan dalam penelitian ini dengan menggunakan penelitian asosiatif dengan tujuan untuk mengetahui hubungan dan pengaruh antara variabel bebas atau independent variable dalam penelitian ini yaitu Etika Kepemimpinan (EK), Fungsi Badan Pengawas Internal (BPI), Pengalaman Kerja (PK), dan Tingkat Pemahaman Akuntansi (TPA) terhadap variabel terikat yaitu Kualitas Pelaporan Keuangan (KPK) sehingga dianalisis untuk meningkatkan kinerja LPD di Kota Denpasar.

Sumber Data dalam penelitian ini adalah data primer yang dilakukan melalui penyebaran kuesioner /angket kepada LPD di Kota Denpasar, sedangkan data sekunder adalah data jumlah LPD yang ada di kota Denpasar. Populasi dalam penelitian ini adalah ketua, badan pengawas, staf akunting yang bekerja di LPD yang ada di Kota Denpasar terdapat 35 LPD di Kecamatan Denpasar Utara, Denpasar Timur, Denpasar Selatan, Denpasar Barat. Pengambilan sampel penelitian ini menggunakan Sampling Jenuh dengan semua LPD sebanyak 35 unit diteliti di Kota Denpasar. Pengumpulan data dilakukan dengan kuesioner yaitu teknik pengumpulan data dengan cara memberikan seperangkat pertanyaan atau pernyataan tertulis kepada pengelola LPD yang ada di kota Denpasar, selain itu dilakukan dokumentasi dengan menghimpun dan menganalisis dokumen-dokumen, baik tertulis, gambaran maupun elektronik.

Analisis data yang dilakukan dengan pengujian validitas untuk mengetahui sejauh mana ketepatan dan kecermatan alat ukur dalam melakukan fungsinya. Ketentuan pada suatu instrumen dikatakan valid atau sah apabila memiliki koefisien pearson correlation > 0,03 dan signifikansi $<0,05$. Uji Reliabilitas jika memberikan nilai cronbach alpha > 0,07 . Reliabilitas atau keandalan instrumen artinya bila instrumen tersebut digunakan untuk mengukur objek yang sama dengan alat pengukuran yang sama akan menghasilkan data yang sama.

Statistik deskriptif adalah statistik ini dilakukan untuk mengetahui keberadaan variabel mandiri, baik hanya pada satu variabel atau lebih (variabel yang berdiri sendiri atau variabel bebas) tanpa membuat variabel itu sendiri dan mencari hubungan dengan variabel lain. Uji Asumsi klasik dilakukan untuk menentukan ketepatan model perlu dilakukan pengujian atas beberapa asumsi klasik yaitu uji normalitas, uji multikolinearitas, dan uji heteroskedastisitas

Pengujian hipotesis digunakan dengan melakukan analisis linear berganda dan diuji dengan tingkat signifikan 0,05 . Analisis linear berganda digunakan untuk mengukur pengaruh satu atau lebih variabel bebas terhadap variabel terikat. digunakan program SPSS. Adapun persamaan model regresi linear berganda yang dipergunakan adalah :

$\mathrm{KPK}=\alpha+\beta 1 \mathrm{EK}+\beta_{2} \mathrm{BPI}-\beta_{3} \mathrm{PK}+\beta_{4} \mathrm{TPA}+\mathrm{e}$

Keterangan:

KPK $=$ Kualitas Pelaporan Keuangan

$\alpha=$ Konstanta 
$\mathrm{EK}=$ Etika Kepemimpinan

BPI $=$ Fungsi Badan Pengawas Internal

$\mathrm{PK}=$ Pengalaman Kerja

TPA $=$ Tingkat Pemahaman Akuntansi

$\beta_{1} \beta_{2} \beta_{3} \beta_{4}=$ Koefisien Regresi

$\mathrm{e}=$ Variabel Pengganggu

\section{Hasil dan Pembahasan}

Responden yang digunakan dalam penelitian ini adalah pihak yang mengetahui tugas, wewenang dan fungsi Badan Pengawas pada LPD di Kota Denpasar dimana pengurus terdiri dari Kepala, akunting atau staf akunting yang bertugas membuat laporan keuangan LPD. Kuesioner yang diisi adalah 4 pada masing-masing LPD yang ada di Kota Denpasar, sehingga jumlah sebaran kuesioner sebanyak 140 kuesioner. Pada pengujian validitas data pada masing-masing indikator variabel mempunyai nilai Pearson Correlation lebih besar dari 0,30 dan nilai sig 2 tailed lebih kecil dari 0,05 , sehingga indikator setiap pertanyaan dalam penelitian ini tepat sebagai pengukuran variabel yang diamati. Pengujian reliabilitas mampu menunjukan sejauh mana instrumen dapat dipercaya, sehingga hasil pengujiannya dilihat dari nilai Cronbach's Alpha untuk masingmasing variabel $>0,07$ dan penelitian ini memberikan hasil yang konsisten.

Uji kelayakan model membuktikan ketepatan fungsi regresi sampel dalam menentukan nilai akrual dengan cara mengukur dari nilai koefisien determinasi, nilai statistik F dan nilai statistik t. Pada penelitian ini nilai koefisien determinasi diukur dengan Adjusted $R$ Square. Hasil analisis koefisien determinasi dapat dilihat pada Tabel berikut :

Tabel 1 Hasil Uji Koefisien Determinasi

\begin{tabular}{llccc}
\hline Model & $\mathrm{R}$ & R Square & Adjusted R Square & $\begin{array}{l}\text { Std.Error of the } \\
\text { Estimate }\end{array}$ \\
\hline 1 & 0,773 & 0,791 & 0,780 & 2,56375 \\
\hline
\end{tabular}

Sumber : Data diolah (2021)

Nilai koefisien determinasi (Adjusted $R$ Square) sebesar 0,780 atau 78 persen. Kualitas pelaporan keuangan dapat dijelaskan sebesar 78 persen oleh etika kepemimpinan, fungsi badan pengawas, pengalaman kerja, dan tingkat pemahaman akuntansi sedangkan sisanya 22 persen dijelaskan oleh faktor selain model.

Uji $\mathrm{F}$ yaitu dengan membandingkan tingkat signifikansi 0,05. Jika nilai probabilitas $<0,05$ maka $\mathrm{H} 1$ diterima, namun jika nilai probabilitas $>0,05$ maka $\mathrm{H} 1$ ditolak. Hasil uji statistik F dapat dilihat pada tabel sebagai berikut.

Tabel 2 Hasil Uji F (Uji secara simultan)

\begin{tabular}{lrrrrr}
\hline \multicolumn{1}{c}{ Model } & Sum of Squares & df & Mean Square & \multicolumn{1}{c}{ F } & \multicolumn{1}{c}{ Sig } \\
\hline Regression & 85,264 & 4 & 22,041 & 4,257 & 0,001 \\
\hline Residual & 532,214 & 135 & 5,139 & & \\
\hline
\end{tabular}




\begin{tabular}{lll}
\hline Total & 617,480 & 139
\end{tabular}

Sumber : Data diolah (2020)

Berdasarkan tabel uji $\mathrm{F}$ diketahui nilai F-test sebesar 4,257 dengan signifikansi sebesar 0,001 lebih kecil dari 0,05 sehingga secara simultan etika kepemimpinan, fungsi badan pengawas, pengalaman kerja, dan tingkat pemahaman akuntansi berpengaruh terhadap kualitas pelaporan keuangan pada LPD di Kota Denpasar. Regresi linier berganda mengandung makna bahwa dalam suatu persamaan regresi terdapat satu variabel dependen dan lebih dari satu variabel independen. Alat analisis ini digunakan untuk mengetahui pengaruh antara variabel bebas dengan variabel terikat (Sugiyono, 2018). Hasil pengujiannya dapat dilihat pada tabel berikut.

Nilai konstanta $(\alpha)$ sebesar 17,805 artinya jika etika kepemimpinan, fungsi badan pengawas, pengalaman kerja, dan tingkat pemahaman dianggap konstan, maka variabel kualitas pelaporan keuangan menunjukkan nilai sebesar 17,805. Etika kepemimpinan mempunyai koefisien regresi sebesar 0,213 dengan tingkat signifikansi sebesar 0,021 artinya kenaikan satu satuan variabel etika kepemimpinan akan menyebabkan peningkatan variabel kualitas pelaporan keuangan sebesar 0,213 dengan variabel lain konstan. Fungsi badan pengawas mempunyai koefisien regresi sebesar 0,102 dengan tingkat signifikansi sebesar 0,040 artinya kenaikan satu satuan variabel fungsi badan pengawas akan menyebabkan peningkatan variabel kualitas pelaporan keuangan 0,102 dengan variabel lain konstan. Pengalaman kerja mempunyai koefisien regresi sebesar 0,112 dengan tingkat signifikansi sebesar 0,061 berarti variabel pengalaman kerja tidak berpengaruh terhadap kualitas pelaporan keuangan. Tingkat pemahaman akuntansi mempunyai koefisien regresi sebesar 0,231 dengan tingkat signifikansi sebesar 0,039 artinya kenaikan satu satuan variabel etika kepemimpinan akan menyebabkan peningkatan variabel kualitas pelaporan keuangan sebesar 0,231 dengan variabel lain konstan.

Tabel 3 Hasil Uji Regresi Linier Berganda

\begin{tabular}{|c|c|c|c|c|c|}
\hline \multirow[t]{2}{*}{ Model } & \multicolumn{2}{|c|}{ Unstandardized Coefficients } & \multirow{2}{*}{$\begin{array}{c}\text { Standardized } \\
\text { Coefficients } \\
\text { Beta }\end{array}$} & \multirow[t]{2}{*}{$\mathrm{t}$} & \multirow[t]{2}{*}{ Sig } \\
\hline & B & Std Error & & & \\
\hline Constant & 17,805 & 4,514 & & 3,875 & 0,000 \\
\hline EK & 0,213 & 0,091 & 0,203 & 2,125 & 0,021 \\
\hline $\mathrm{BP}$ & 0,102 & 0,068 & 0,143 & 1,510 & 0,040 \\
\hline $\mathrm{PK}$ & $-0,112$ & 0,061 & $-0,175$ & $-1,758$ & 0,061 \\
\hline TPA & 0,231 & 0,080 & 0,274 & 2,861 & 0,039 \\
\hline
\end{tabular}

Sumber : Data diOlah (2020)

$\mathrm{KPK}=17,805+0,213 \mathrm{EK}+0,102 \mathrm{BP}-0,112 \mathrm{PK}+0,231$

TPA.....................(1) 


\section{Pengaruh Etika Kepemimpinan Terhadap Kualitas Pelaporan Keuangan pada LPD di Kota Denpasar.}

Etika kepemimpinan membawa dampak yang positif terhadap Kualitas Pelaporan Keuangan di LPD kota Denpasar. Hasil tersebut sesuai dengan hipotesis yang diutarakan berdasarkan nilai signifikansi $0,021<0,05$ dan hipotesis dapat diterima.

Karakteristik terpenting yang dilakukan seorang pemimpin agar perusahaannya berjalan dengan baik dan berkembang sehingga tercapai manfaat bersama berdasarkan norma dan nilai yang berlaku sebagai konsep dari etika kepemimpinan. Laporan keuangan yang dibuat oleh LPD tersebut tidak akan direkayasa oleh karyawan selama pemimpin mempunyai etika yang baik, dan diikuti oleh karyawannya, sehingga etika kepemimpinan sangat penting dalam menentukan kualitas laporan keuangan LPD. Semakin meningkat etika seorang pemimpin LPD maka kualitas laporan keuangan yang disajikan akan semakin baik. Penelitian didukung oleh Ho et al., (2019) ; Mabil (2019) ; dan Yanti (2019).

\section{Pengaruh Fungsi Badan Pengawas Terhadap Kualitas Pelaporan Keuangan pada LPD di Kota Denpasar.}

Fungsi Badan Pengawas membawa dampak yang positif terhadap Kualitas Pelaporan Keuangan di LPD kota Denpasar. Hasil tersebut sesuai dengan hipotesis yang diutarakan berdasarkan nilai signifikansi 0,040 $<0,05$ dan hipotesis dapat diterima.

Sistem akuntansi keuangan yang sudah ditetapkan sesuai standar pelaporan akuntansi akan menopang kualitas laporan keuangan, selain itu badan pengawas berfungsi dalam mengawasi dokumen laporan yang dibuat LPD. Fungsi badan pengawas sudah dilakukan dengan baik dalam menjalankan tugasnya sehingga kualitas laporan keuangan dapat dipercaya oleh masyarakat. Semakin meningkat fungsi badan pengawas LPD maka kualitas laporan keuangan yang disajikan akan semakin baik, dan kepercayaan masyarakat semakin meningkat. Penelitian didukung oleh Bao \& Lewellyn (2017) ; Lestari \& Oktaviana (2019); dan Sari \& Setyowati (2021).

\section{Pengaruh Pengalaman Kerja Terhadap Kualitas Pelaporan Keuangan pada LPD di Kota Denpasar.}

Pengalaman kerja tidak membawa dampak terhadap Kualitas Pelaporan Keuangan di LPD kota Denpasar. Hasil tersebut tidak sesuai dengan hipotesis yang diutarakan berdasarkan nilai signifikansi $0,061<0,05$ dan hipotesis dinyatakan ditolak.

Pengalaman kerja yang sudah dimiliki bagi pengelola LPD berdasarkan laporan keuangan yang disajikan sesuai dengan standar akuntansi keuangan dan sesuai dengan ketentuan aturan tidak membawa pengaruh terhadap kualitas laporan keuangan karena sudah menggunakan tolok ukur pelaporan keuangan yang sudah ditetapkan, sehingga karyawan yang sudah berpengalaman tidak berdampak dalam kualitas laporan keuangan LPD tersebut.Penelitian ini berbeda dengan Balakrishnan\& Ertan (2018) ; Sukarini \& Dewi (2019) ; dan Mulia (2019). Penelitian ini didukung oleh Sugiatmoko (2020) ; dan Emillia, dkk. (2020). 


\section{Pengaruh Tingkat Pemahaman Akuntansi terhadap Kualitas Pelaporan Keuangan pada LPD di Kota Denpasar.}

Pemahaman akuntansi membawa dampak yang positif terhadap Kualitas Pelaporan Keuangan di LPD kota Denpasar. Hasil tersebut sesuai dengan hipotesis yang diutarakan berdasarkan nilai signifikansi $0,039<0,05$ dan hipotesis dapat diterima.

Tingkat pemahaman akuntansi yang dimiliki khususnya pengelola LPD bagian keuangan dapat mencerminkan kualitas laporan keuangan yang disajikan LPD tersebut. Pemahaman akuntansi yang baik yang dilakukan oleh staf keuangan akan mengurangi kesalahan dalam pembuatan laporan keuangan sehingga output laporan keuangan yang disajikan berkualitas, dapat berguna bagi stakeholdernya, dan berfungsi sebagai pengambil keputusan kinerja LPD berikutnya.Apabila tingkat pemahaman akuntansi semakin meningkat maka akan dapat meningkatkan kualitas laporan keuangan LPD tersebut. Penelitian ini sejalan dengan penelitian Jha (2019) ; Riyadi (2020) ; dan Yanti \& Nurhidayah (2020).

\section{Simpulan dan Saran}

Berdasarkan hasil pengujian, hasil penelitian dapat disimpulkan Etika Kepemimpinan, fungsi badan pengawas, dan tingkat pemahaman akuntansi berpengaruh positif terhadap kualitas laporan keuangan pada LPD di Kota Denpasar. Sedangkan pengalaman kerja tidak berpengaruh terhadap kualitas laporan keuangan pada LPD di Kota Denpasar.Untuk peningkatan kinerja pengelola LPD khususnya ketua harus mengutamakan etika kepemimpinan, selain itu fungsi badan pengawas selalu ditingkatkan dan mengacu pada prosedur sesuai aturan penyajian laporan keuangan. Dan pemahaman akuntansi juga terus ditingkatkan. Pelatihan terhadap karyawan terus ditingkatkan karena lebih memberikan peranan kerja pada LPD sehingga kinerja LPD kota Denpasar terus meningkat.

\section{Daftar Pustaka}

Agung, M. F., \& Mulyani, S. 2020. "Pengaruh Good Governance Dan Latar Belakang Profesi Kepala Daerah Terhadap Kualitas Laporan Keuangan Dan Kinerja Pemerintah Daerah". Jurnal SIKAP (Sistem Informasi, Keuangan, Auditing Dan Perpajakan), 4(2), 142-159.

Agustina, N., \& Setyaningrum, D. 2020. "Determinants Quality of Local Government Financial Statements in Indonesia". Review of Integrative Business and Economics Research, 9, 226-239.

Alferjany, A. A. M., Salama, A. A., Amuna, Y. M. A., Al Shobaki, M. J., \& Naser, S. S. A. 2018. "The Relationship between Correcting Deviations in Measuring Performance and Achieving the Objectives of Control-The Islamic University as a Model". International Journal of Engineering and Information Systems (IJEAIS), 2(1), 74-89.

Arowoshegbe, A. O., Uniamikogbo, E., \& Atu, G. 2017. "Accounting Ethics and Audit Quality in Nigeria". Asian Journal of Economics, Business and Accounting, 1-15.

Balakrishnan, K., \& Ertan, A. 2018. "Banks' financial reporting frequency and asset quality". The Accounting Review, 93(3), 1-24. 
Bao, S. R., \& Lewellyn, K. B. 2017. "Ownership structure and earnings management in emerging markets", An institutionalized agency perspective. International Business Review, 26(5), 828-838.

Charolina, O., Husaini, H., \& Abdullah, A. 2013. "Pengaruh Implementasi Pengelolaan Keuangan dan Pengalaman Kerja terhadap Kualitas Laporan Keuangan Komisi Pemilihan Umum.” Jurnal Fairness, 3(3), 313-326.

Dewi, N., Azam, S., \& Yusoff, S. 2019. "Factors influencing the information quality of local government financial statement and financial accountability". Management Science Letters, 9(9), 1373-1384.

Ellemers, N. 2017. Morality and the regulation of social behavior: Groups as moral anchors. Psychology Press.

Emillia, N. K., Herawati, H., \& Yunilma, Y. 2020. "Pengaruh Profesionalisme, Independensi, Dan Pengalaman Kerja Terhadap Kualitas Audit Dengan Etika Profesi Sebagai Variabel Moderasi (Studi Empiris pada KAP di Padang dan Pekanbaru tahun 2020) “ Doctoral dissertation, Universitas Bung Hatta.

Goddard, A. 2020. "Accountability and accounting in the NGO field comprising the UK and Africa-A Bordieusian analysis". Critical Perspectives on Accounting, 102200 .

Holt, S., Hall, A., \& Gilley, A. 2018. "Essential components of leadership development programs". Journal of Managerial Issues, 30(2), 214-153.

Ho, S. S., Li, A. Y., Tam, K., \& Zhang, F. 2015. "CEO gender, ethical leadership, and accounting conservatism. Journal of Business Ethics, 127(2), 351-370.

Ivancevich, John M.(2001). Human resource management. Edisi ; 8 th, Boston ; McGraw-Hill.

Jha, A. 2019." Financial reports and social capital." Journal of Business Ethics, 155(2), 567-596.

Lantto, A. M. 2020. "Obtaining entity-specific information and dealing with uncertainty: Financial accountants' response to their changing work of financial reporting and the role of boundary objects." Critical Perspectives on Accounting, 102277.

Lestari, I. F., \& Oktaviana, U. K. 2020. "Peranan komite audit dan dewan pengawas syariah terhadap kualitas laporan keuangan (studi kasus pada BPRS di Jawa Timur”. El Dinar, 8(1), 29-36.

Mabil, A. N. 2019. "Investigating effects of accounting ethics on quality of financial reporting of an organization: case of selected commercial banks in South Sudan". Mediterranean Journal of Social Sciences, 10(1), 177-177.

Mulia, R. A. 2019. "Analisis Faktor-Faktor Yang Mempengaruhi Kualitas Laporan Keuangan Pemerintah Daerah"Jurnal EL-RIYASAH, 9(1), 7-21.

Munirah, M. P. 2020.Menjadi guru beretika dan profesional. Insan Cendekia Mandiri. 
Nuraini, Maya 2007. "Pengaruh Kecerdasan Emosional dan Minat Belajar Mahasiswa Akuntansi Terhadap Tingkat Pemahaman akuntansi". Jurnal BETA, Gresik, Maret.

Purba, S., Astuti, A., Gulo, J., Nur, N. K., Hastuti, P., Boy, E.,\& Prasasti, L. 2020. Etika Profesi: Membangun Profesionalisme Diri. Yayasan Kita Menulis.

Putri, L. P. Y. K., \& Withnall, E. G.2018. "Protecting the Village Credit Institution: Should Traditional Communities Adopt Modern Financial Management Practices?." Udayana Journal of Law and Culture, 2(2), 115-139.

Petrakis, P. E. 2020. Theoretical Approaches to Economic Growth and Development. Springer Books.

Permatasari, N. K. I., \& Agustina, M. D. P. 2021. "Analisis Tingkat Kesehatan LPD Metode Capital, Assets, Management, Earning dan Liquidity LPD Desa Baluk Negara Periode 2016-2018”. Widya Amrita: Jurnal Manajemen, Kewirausahaan dan Parwisata, 1(1), 265-274.

Rahayu, K. P., Wati, R., Prihanto, Y., Wartono, T., \& Nuryani, Y. 2020. "Pelatihan Audit Internal Penggunaan Dana Bos untuk Kepala Sekolah, Bendahara, Administrasi SMP Kota Tangerang Selatan Gugus 03". DEDIKASI PKM, 1(2), 6-12.

Riyadi, W.2020. "Pemanfaatan Sistem Informasi Akuntansi Dan Pemahaman Akuntansi Pengaruhnya Terhadap Kualitas Laporan Keuangan Pada Koperasi Di Kabupaten Majalengka." J-AKSI, 1(2), 55-72.

Sari, A. P. A. M. P., \& Suindari, N. M. 2020.” Pengaruh Kesehatan LPD, Jumlah Nasabah dan Suku Bunga Terhadap Profitabilitas Melalui Pertumbuhan Aset”. Akurasi: Jurnal Studi Akuntansi dan Keuangan, 3(2), 130-150.

Sari, N. Z., \& Susanto, A. 2018. "The effect of auditor competency and work experience on information systems audit quality and supply chain" International Journal of Supply Chain Management (IJSCM), 7(5), 732-747.

Sari, H. C., \& Setyowati, E. 2021. "Pengaruh Efektivitas Fungsi Audit Internal Dan Implementasi Pemerintahan Berbasis Akrual Standar Akuntansi Tentang Pelaporan Keuangan Kualitas". In Economic, Bussines, and Accounting of Conference Ahmad Dahlan (Vol. 1, No. 2).

Sugiatmoko, F. A. 2020. "Pengaruh Kualitas Auditor Terhadap Kualitas Audit” Doctoral dissertation, UNIVERSITAS AIRLANGGA).

Sugiyono.2018. Metode Penelitian Kombinasi (Mixed Methods). Bandung: CV Alfabeta.

Sukarini, L., \& Dewi, P. E. D. M. 2019. "Pengaruh tingkat pendidikan, pengalaman kerja, pelatihan, dan penggunaan teknologi informasi terhadap kualitas laporan keuangan BUMDes di Kecamatan Negara.” JIMAT (Jurnal Ilmiah Mahasiswa Akuntansi) Undiksha, 9(3).

Wedayani, N. W., \& Jati, I. K. 2012. "Efektivitas Fungsi Badan Pengawas Sebagai Internal Auditor Dalam Pengawasan Terhadap Pemberian Kredit Pada LPD Di Kecamatan Rendang, Selat, Sidemen, dan Manggis Kabupaten Karangasem, Provinsi Bali”. Jurnal Ilmiah Akuntansi dan Humanika, 1(2). 
Yanti, N. P. M. D. 2019. "Pengaruh Etika Kepemimpinan Dan Tingkat Pemahaman Akuntansi Terhadap Kualitas Pelaporan Keuangan Pada PT. Raditya Dewata Perkasa”. JSAM (Jurnal Sains, Akuntansi dan Manajemen), 1(2), 271-299.

Yanti, A., \& Nurhidayah, F. 2020.” Pentingnya Pemahaman Akuntansi Sederhana Sebagai Solusi Untuk Menyusun Laporan Keuangan”. JURNAL AKUNTANSI, 9(2), 186-193.

Zulkarnain, Z., \& Ningrum, D. A. 2020. "Determinan Kualitas Laporan Keuangan Pemerintah Daerah Kota Sukabumi”. Syntax Literate; Jurnal Ilmiah Indonesia, 5(5), 197-211. 